\title{
Pinch sign for acute lateral cutaneous nerve entrapment syndrome (LACNES)
}

\author{
Takashi Watari ${ }^{1,2}$
}

'Shimane University Faculty of Medicine Graduate School of Medicine, Izumo, Shimane, Japan

${ }^{2}$ Master of Healthcare Quality and Safety, Harvard Medical School, Boston, Massachusetts, USA

\section{Correspondence to} Dr Takashi Watari; wataritari@gmail.com

Accepted 28 January 2021
Check for updates

(c) BMJ Publishing Group Limited 2021. No commercial re-use. See rights and permissions. Published by BMJ.

To cite: Watari T. BMJ Case Rep 2021;14:e241421. doi:10.1136/bcr-2020241421

\section{DESCRIPTION}

An 18-year-old woman with no remarkable medical history presented with sudden onset of left-sided abdominal pain that manifested after she bent forward in her chair to pick something up. The pain intensified whenever she rotated her trunk. The day before visiting my centre, she visited another hospital where she was diagnosed with unexplained abdominal pain and prescribed painkillers. These drugs did not provide pain relief. Her contrastenhanced thoracoabdominal CT findings were unremarkable.

When I examined her, she rated her pain intensity as 8 on a 10-point scale. She experienced locoregional flank pain affecting the Th8 vertebra. Physical examination revealed a small maximally sensitive spot along the midaxillary line (video 1 ). Pinching this spot and lifting the skin elicited intense pain, and light pulling elicited sharp pain (pinch sign positive). Furthermore, thermosensitivity and pain sensitivity differed in each side of her body.

I diagnosed her with acute lateral cutaneous nerve entrapment syndrome (LACNES). ${ }^{1}$ I prescribed a $5 \mathrm{~mL}$ local injection of $1 \%$ lidocaine and within $10 \mathrm{~min}$, her self-reported local pain intensity decreased from 8 to 0 on the 10 -point scale. At a follow-up phone call 3 months later, her pain had completely disappeared.

LACNES is a subtype of anterior cutaneous nerve entrapment syndrome (ACNES). Maatman et $a l^{1} 2$ indicated that LACNES is an underdiagnosed form of neuropathic flank pain caused by disturbances in the lateral cutaneous branches of the intercostal nerves arising from the Th7-12 vertebrae. To diagnose LACNES, Maatman et al ${ }^{1}$ suggested that three of the following criteria should be met: (1) $>3$ months history of locoregional flank pain; (2) a fingertip-sized area of constant tenderness in the flank along the midaxillary line, with pressure eliciting high-intensity pain; (3) altered skin sensations - such as hypoesthesia, hyperesthesia or altered cold perception-in surrounding areas; and (4) negative pinch test results surrounding the tender spot. This present case met all but the first of these criteria.

In a retrospective analysis of 30 patients with LACNES $(70 \%$ women; median age, 52 years; range, 13-78 years) who met all the criteria of Maatman et al, the median time from onset to diagnosis was $>18$ months. For unclear reasons, pain was more common on the right side. The skin pinch test yielded positive results in $90 \%$ of patients. All cases were treated with $5-10 \mathrm{~mL}$ of $1 \%$ lidocaine

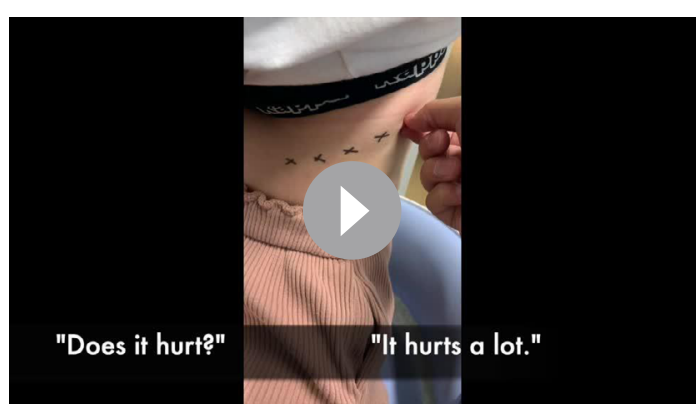

Video 1 Typical pinch sign positive. Pinching the point indicated elicited very intense, momentary pain.

injection, which represents trigger point injections used to treat ACNES, and the long-term efficacy rate was $>50 \% .^{23}$ However, local lidocaine injections may be ineffective in patients with spatially extensive pain. Regional neurotomy and pulsed radiofrequency therapy reportedly provide longterm pain relief. However, their effectiveness is unconfirmed. ${ }^{13}$

Despite recent advances in imaging technology, LACNES is considered an underdiagnosed condition. $^{145}$ To establish a definitive diagnosis in patients with unidentifiable pain, physicians must carefully investigate pain duration, extent of the nociceptive dermatome, presence or absence of a pinch sign and circumstances in which pain is induced while considering differential diagnosis as shown in Box 1.

Physicians should also consider LACNES as a potential diagnosis when determining whether pain is neuropathic.

\section{Box 1 Differential diagnosis of LACNES}

LACNES-like pain

- Abdominal myofascial pain syndrome

- Abdominal wall (haematoma, endometriosis, tumour, tear)

- Radiculopathy (diabetic, traumatic)

- Scar tissue

- Slipping rib syndrome

- Rib abnormalities

- Postherpetic neuralgia

- Neurofibroma

- Schwannoma

- Herniated disk

LACNES, lateral cutaneous nerve entrapment syndrome. 


\section{Learning points}

Lateral cutaneous nerve entrapment syndrome (LACNES) is a subtype of anterior cutaneous nerve entrapment syndrome and may easily be underdiagnosed.

- The most useful finding for clinical diagnosis is the pinch sign.

- Physicians should consider LACNES as a potential diagnosis when evaluating atypical lateral thoracic or lateral abdominal pain.

Acknowledgements I want to thank all the members of Teki-Teki-Sai 21 in Japan for their constructive discussion.

Contributors TW cared for the patient and wrote this whole manuscript.

Funding The author has not declared a specific grant for this research from any funding agency in the public, commercial or not-for-profit sectors.
Competing interests None declared.

Patient consent for publication Obtained.

Provenance and peer review Not commissioned; externally peer reviewed.

\section{REFERENCES}

1 Maatman RC, Papen-Botterhuis NE, Scheltinga MRM, et al. Lateral cutaneous nerve entrapment syndrome (LACNES): a previously unrecognized cause of intractable flank pain. Scand J Pain 2017:17:211-7.

2 FMU M, Maatman RC, De Joode L. Characteristics of 1,116 consecutive patients diagnosed with anterior cutaneous nerve entrapment syndrome (acnes). Ann Surg 2019.

3 Boelens OBA, Scheltinga MR, Houterman S, et al. Randomized clinical trial of trigger point infiltration with lidocaine to diagnose anterior cutaneous nerve entrapment syndrome. Br J Surg 2013;100:217-21.

4 Peleg R, Gohar J, Koretz M, et al. Abdominal wall pain in pregnant women caused by thoracic lateral cutaneous nerve entrapment. Eur J Obstet Gynecol Reprod Biol 1997;74:169-71.

5 Sharf M, Shvartzman P, Farkash E, et al. Thoracic lateral cutaneous nerve entrapment syndrome without previous lower abdominal surgery. J Fam Pract 1990;30:211-4.

Copyright 2021 BMJ Publishing Group. All rights reserved. For permission to reuse any of this content visit

https://www.bmj.com/company/products-services/rights-and-licensing/permissions/

BMJ Case Report Fellows may re-use this article for personal use and teaching without any further permission.

Become a Fellow of BMJ Case Reports today and you can:

- Submit as many cases as you like

- Enjoy fast sympathetic peer review and rapid publication of accepted articles

- Access all the published articles

Re-use any of the published material for personal use and teaching without further permission

Customer Service

If you have any further queries about your subscription, please contact our customer services team on +44 (0) 2071111105 or via email at support@bmj.com.

Visit casereports.bmj.com for more articles like this and to become a Fellow 